\title{
Population Briefs, Vol. 8, no. 1
}

Population Council

Follow this and additional works at: https://knowledgecommons.popcouncil.org/ series_newsletters_popbriefs How does access to this work benefit you? Let us know!

\section{Recommended Citation}

Population Briefs 8(1). New York: Population Council, 2002. 
IN THISISSUE

- Epidemiology

- Urban Studies

- Demography

- Basic Research

- Women's Health

- Microbicides

“Education, health,

and literacy are

particularly crucial

to the completion

of the fertility

transition."

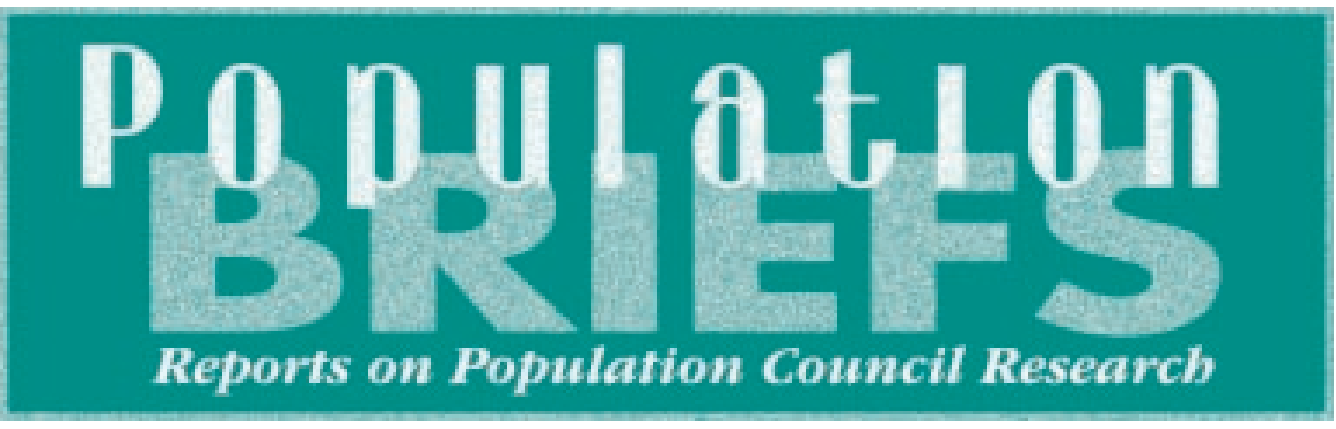

J uly 2002

Volume 8, Number 1

\section{What Factors Affect the Prevalence of HIV in sub-Saharan Africa?}

Morethan 3 million of the 5 million people who were newly infected with HIV in 2001 live in subSaharan Africa, according to UNADS. The vast majority of HIV-infected adults in Africa acquired their infection through heterosexual intercourse. Over the decades since the AIDS epidemic was first noted, researchers have observed that the prevalence of HIV infection within Africa varies greatly. While many areas in East and Southern Africa experience high rates of infection, regions in West and Central Africa generally have lower infection rates. Anumber of theories to explain these disparities have been put forth. But until now there have been no systematic studies to directly address this matter.

Two Population Council researchers, Jane Chege, then based in Nairobi, Kenya, and Naomi Rutenberg, based in Washington, DC, participated along with several other investigators in a recent study on HIV. Chege is now based in Johannesburg, South Africa. The findings of the investigation, known as the multicentre study of factors determining the different prevalences of HIV in sub-Saharan Africa, were presented in a special supplement to the journal ADS The Population Council collaborated on the study design and questionnaires and collected data in one location, Kisumu, Kenya. Chege and Rutenberg assessed data quality and anal yzed data at the population and individual level. This analysis suggested further avenues of investigation, which were pursued by the other scientists. The research findings indicate that changes in HIV-prevention policy are urgently needed.
The researchers investigated HIV epidemics in four cities. Two of these cities- Kisumu and Ndola, Zambia, in East and Southern Africa - have a high HIV prevalence. And two - Cotonou, Benin and Yaoundé, Cameroon, in West and Central Africa- have a low and stable HIV prevalence. In each of these cities, researchers selected approximately 1,000 men and 1,000 women aged 15- 49 years from the general population. Those who agreed to participate were interviewed about sexual behaviors and other factors that might influence their susceptibility to HIV infection. They were tested for HIV and a number of other sexually transmitted infections (STIs).

\section{HIV prevalence in young women}

The HIV testing conducted as part of the study confirmed a high HIV prevalencein Kisumu and Ndola. It also underlined the greater risk of infection experienced by women, particularly young women, compared to men.

A group of researchers, including Chege, anaIyzed the statistics from Kisumu and Ndola. They found that among sexually active 15-19-year-olds in both sites, HIV was six times more prevalent in women than in men. Among 20-24-year-olds, the infection was three times more prevalent in women. HIV was equally widespread among women and men in the 25- 49 year age group.

Behavioral factors did not seem to explain this difference in HIV susceptibility. The presence of 


\section{Public Services Found Lacking in Many Developing-Country Cities}

In the cities of less-developed countries, many households are not outfitted with running water, sanitary waste disposal, and electricity. Poor water quality and inadequate sanitation are associated with increased incidence of diarrheal diseases, such as cholera, and other bacterial pathogens. Furthermore, these diseases can recur and affect health in the long term by reducing the uptake of nutrients, which in turn stunts growth and causes wasting. Children living without these basic public services also suffer from elevated mortality and other health risks. Lack of electricity can influence nutrition directly, by limiting refrigeration and food storage, and indirectly, by reducing economic production and incomes.

Population Council demographers Paul C. Hewett and Mark R. Montgomery recently completed a comprehensive examination of the availability of services in cities and towns of developing countries around the world. Using data from the Demographic and Health Surveys of 43 countries, they discovered striking differences in the distribution of these basic services. Moreover, recent political changes underway in many developing countries may be making the delivery of basic services more difficult.

\section{Smaller cities and the urban poor}

Research has often detailed the extreme deprivation in rural areas of developing countries. In rural sub-Saharan Africa, for instance, nearly 90 percent of households (representing more than 350 million people) lack running water, flush toilets, and electricity. However, "in addition to highlighting the needs of the rural poor," says Hewett, "our research suggests that the circumstances of the urban poor, particularly those in smaller cities, require attention." The United Nations projects that in the next quarter-century, more than 90 percent of world population growth will occur in urban areas of developing countries.

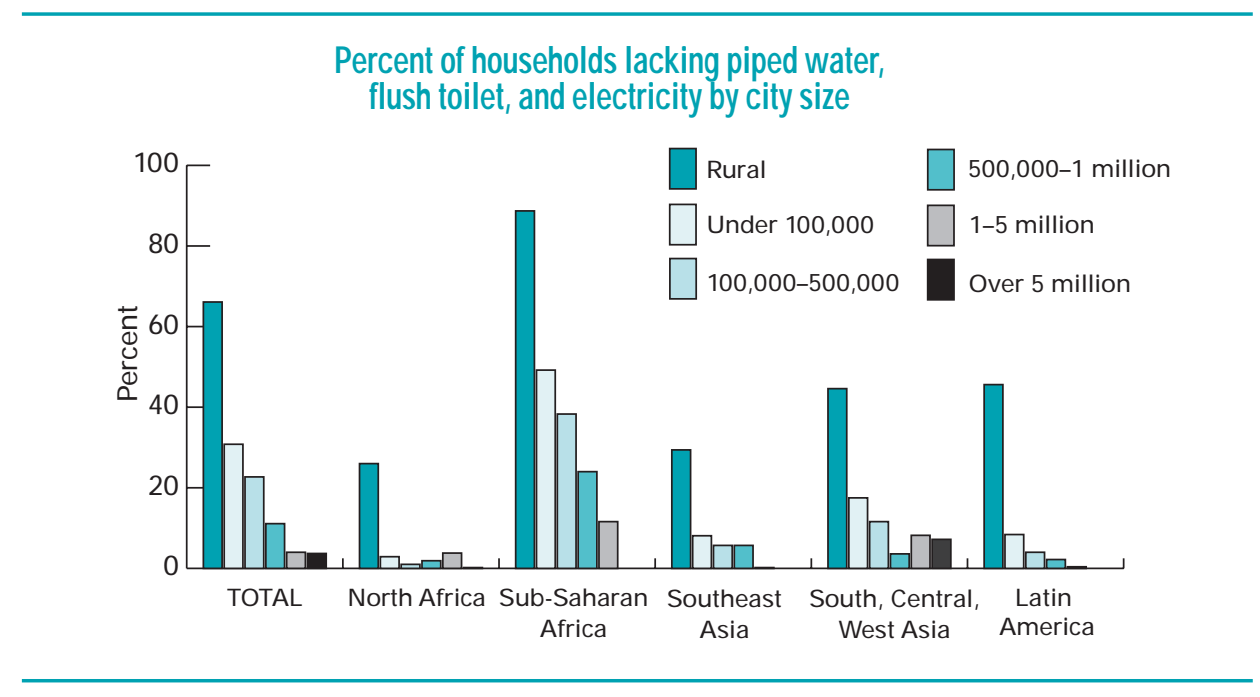

By distinguishing urban areas by size rather than merely focusing on differences between urban and rural areas or on the largest cities, Hewett and Montgomery found that people who live in smaller cities are much less likely to have basic services than are people who live in larger cities. For instance, nearly 50 percent of households in the cities of subSaharan Africa with populations under 100,000 lack piped water, flush toilets, and electricity. Similar deficits in the availability of basic services exist in the smaller cities of Asia and Latin America.

"We al so found sharp inequalities in access to public services between the urban poor and other urban residents," says Hewett. The largest differences emerge in access to electricity, which in sub-Saharan African countries is available to only a quarter of the urban poor but slightly more than half of other urban households. Wide differentials in access are also evident in Southeast Asia, and in South, Central, and West Asia. In Latin America, the greatest differences between the urban poor and other urban residents are seen in access to flush toilets, with smaller (yet still significant) differences in piped water and electricity.

\section{Political decentralization and devolution}

Recent policy changes may stymie efforts to remedy these imbalances. "Many developingcountry governments are decentralizing service delivery, transferring responsibilities from national to local levels without a commensurate transfer of funding," says Montgomery. "This leaves local governments unable to extend public services." In some cases nongovernmental organizations, community-based organizations, and residents' associations have attempted to provide services. The researchers contend, however, that such small groups may not effectively substitute for active national governments. "Until the situation is sorted out, gross inefficiencies and gaps will probably continue to plague the provision of public services," contends Montgomery. .

\footnotetext{
SOURCE

Hewett, Paul C. and Mark R. Montgomery. 2001

"Poverty and public services in developing-country cities." Policy Research Division Working Paper no. 154. New York: Population Council.

OUTSIDE FUNDING
}

The William and Flora Hewlett Foundation, The Andrew W. Mellon Foundation, and the United States Agency for Intemational Development 


\section{Decelerating Pace and Human Development Crucial Elements of Fertility Transition}

In a small number of developing countries fertility has dipped below the replacement level of 2.1 births per woman. Some demographers have asked whether projections of future population growth might be made more accurate by changing them to assume that fertility in the long run will fall below replacement in all countries, rather than to 2.1 births per woman as is now the assumption. If fertility declines to 2.1 births per woman, population will peak in the twenty-second century and then stabilize. If fertility declines to 1.8 or 1.9 births per woman, on the other hand, population will peak late in this century and then begin a slow decline.

In March 2002, a United Nations expert group met to debate the possibility of revising the UN methodology for projecting the course of population growth over the next several decades. Population Council demographer John Bongaarts, one of the experts called to comment on this issue, contends that simply lowering the assumed ultimate fertility level would be insufficient. He recently published research outlining additional changes that would be needed to make the fertility projection model more accurate.

"The UN has been tremendously successful at predicting population growth in the past, but a close look at their projections suggests several ways to improve them," says Bongaarts. A slight reduction in the assumed fertility level at the end of the transition to about 1.9 is a step in the right direction. "Other adjustments are also desirable, although once the necessary adjustments are made, population projections into the middle of this century will still be similar to the current UN projections."

\section{Pace of fertility transition}

The current UN model for future fertility decline does not take into account the changing pace of fertility. The model assumes a linear drop to a stable fertility level of 2.1 births per woman in most developing countries. The research of Bongaarts and other Population Council investigators shows, however, that the speed of fertility decline changes as the transition from high to low fertility progresses.

In his recent study, Bongaarts examined trends and patterns in fertility in the developing world, focusing particularly on the later stages of transition. He sought to identify regularities in the past record that may provide

\section{"Poor countries with}

high levels of health

and education can

have low fertility."

clues to future trends. Bongaarts looked at UN estimates of total fertility rates between the years 1950 and 2000 for all countries of Africa, Asia, and Latin America and the Caribbean except Japan, Australia, and New Zealand. Past fertility trends have been highly variable. Some countries- Singapore and South Korea, for example- proceeded fairly swiftly to belowreplacement-level fertility. Others, mostly in sub-Saharan Africa, still have high fertility. Rapid declines to bel ow replacement are the exception rather than the rule.

Three key features summarize these past transitions. First, fertility is high until the transition begins. Second, once the transition gets underway, fertility declines fairly rapidly. And third, the pace of decline decelerates as countries reach the later stages of the transition. Sometimes the fertility transition stalls above replacement level for decades. These same patterns are likely to prevail in the future, and they should be incorporated in projections. In the future many developing countries will experience slower declines than the UN now assumes.
Bongaarts al so looked at several indicators of development to see whether these had any bearing on the fertility transition. Some observers have argued that, despite conventional wisdom, development may play little role in reducing fertility. "The beginning of the fertility transition is often driven by the diffusion of new ideas about reproductive behavior among individuals, communities, and countries," says Bongaarts. "Education, health, and literacy, however, are particularly crucial to the comple tion of the fertility transition. Wealth is less critical. Poor countries, such as Sri Lanka, with high levels of health and education can have low fertility." Bongaarts's investigation reveal ed that most devel oping countries that have attained near-replacement fertility levels have an average life expectancy of more than 70 years and a literacy level over 90 percent. The large majority of developing countries fall well short of this level of human development. Thus, considerable progress will likely have to be made before near-replacement fertility becomes widespread, Bongaarts contends.

One reason that reaching replacementlevel fertility is difficult is that it requires a high degree of birth control. Diligent, effective use of family planning is needed to avoid unintended pregnancies. "A high-quality family planning program can movea country closer to replacement fertility than would be expected from its level of development al one," explains Bongaarts. "But these programs al one cannot bring about declines in desired family size. Human devel opment is the key to reducing preferences for large families and to completing the transition."

SOURCE

Bongaarts, J ohn. 2002. "The end of the fertility transition in the developing world." Policy Research Division Working Paper no. 161 New York: Population Council.

OUTSIDE FUNDING

The William and Flora Hewlett Foundation, The Andrew W. Mellon Foundation, and the United States Agency for Intemational Development 


\section{Illuminating the Role of Inhibins and Activins in Fertility}

All currently available hormonal contracep-

tives for women reduce fertility by influencing levels of the steroid hormones estrogen and progesterone. Altering the levels of these hormones, however, can cause unpleasant side effects in some cases. Population Council molecular endocrinologist Daniel Bernard is conducting basic research that may one day lead to a contraceptive for women that leaves estrogen and progesterone levels largely unaffected, theoretically resulting in fewer side effects. His research concerns two types of protein hormones that play a role in women's fertility: inhibins and activins.

\section{Interplay of hormones}

Succesful reproduction is dependent upon the coordinated regulation and actions of hormones created in the brain, the pituitary gland, and the ovary and testis. In women, for example, various hormones stimulate the maturation of egg-containing follicles in the ovaries. They also trigger ovulation and pre pare the uterus for the implantation of fertilized eggs. Feedback loops, in which levels of one hormone influence the production of other hormones, control this monthly cycle.

One vital hormone involved in female fertility is folliclestimulating hormone (FSH). The anterior pituitary gland releases $\mathrm{FSH}$, which then travels to the ovary via the bloodstream. In the ovary, FSH binds to molecular receptors on the surface of cells. The binding of a protein or hormone to a receptor can be thought of as a key entering a lock. When the FSH "key" binds with its receptor "lock," it stimulates the growth of follicles.

Women who cannot produce FSH or its molecular receptors are infertile because their egg-containing follicles are unable to mature. Drugs that block the action of FSH would be likely to produce reversible infertility in women. (FSH does not appear to be necessary for reproduction in men.)

Many hormones regulate the production of FSH. Bernard, however, is most interested in pursuing inhibins, which are produced in the ovary and testis, and activins, which appear to affect FSH through their local production within the pituitary gland. As their names suggest, inhibins hinder and activins stimulate the production and release of FSH from the pituitary. Moreover, these hormones selectively influence FSH production and do not directly affect either estrogen or progesterone production.

\section{"Learning how inhib-}

ins and activins regu-

late FSH is critical to

understanding the

processes governing

normal reproduction."

Investigation into inhibins may al so shed light on some diseases. Research has shown that abnormal inhibin production may contribute to the halt in follicle development seen in polycystic ovary syndrome, a disease that can cause infertility and other complications. And women with a rare form of ovarian cancer frequently have abnormal blood levels of inhibin. Both inhibin and activin are part of a larger family of proteins that seem to act as tumor suppressors.

\section{Gaps in knowledge}

While much has been learned about how activins affect their target cells, there are still gaps in knowl edge. Bernard and his colleagues aim to elucidate the cascade of actions generated within cells after the activin "key" binds to one of its "locks," a receptor known as ActRII. This sequence prompts the production of FSH.

The lab al so seeks to clarify the mechanisms of action used by inhibins. One way that inhibin hampers the production of FSH is by binding to ActRII, thus blocking activin from binding. Research has shown that alone, inhibin binds only weakly to ActRII. When certain other proteins are present, however, inhibin can bind strongly to the receptor.

One of these proteins is known as betaglycan. When inhibins interact with betaglycan and bind to ActRII receptors, they do not appear to set off a cascade of signals within the cell. Rather, they seem to work simply by disrupting activin action. As when the wrong key is put in a lock, the lock will not open and the inserted key prevents the correct key from entering.

Bernard and his team are investigating the possibility that inhibin- receptor binding sets off an unknown process within cells. They are al so searching for proteins in the pituitary gland that are similar to betaglycan and for receptors that may be specific to inhibin - in other words a lock that inhibin can open.

Recently, Bernard and his colleagues discovered and began to characterize a protein, which they named InhBP/p120, that seems to exert some influence over inhibin activity. They showed that InhBP/p120 can form a complex with a different activin receptor, this one called ALK4. When inhibins are added, activin-stimulated gene activity stops al most entirely.

"Learning how inhibins and activins regulate FSH is critical to understanding the processes governing normal reproduction," says Bernard. "Understanding these processes may reveal targets for contraceptives, and may also give us insights into some forms of infertility and certain cancers, as well."

\section{SOURCES}

Bemard, Daniel J ., Stacey C. Chapman, and Teresa K. Woodruff. 2001 "Mechanisms of inhibin signal transduction," Recent Progress in Hormone Research 56: 417-450.

Bernard, Daniel J ., Stacey C. Chapman, and Teresa K. Woodruff. 2002. “Minireview: Inhibin binding protein (InhBP/p120), betaglycan, and the continuing search for the inhibin receptor," Molecular Endocrinology 16(2): 207-212. 


\section{Bridging the Safe Motherhood Knowledge Gap}

A reduction in maternal deaths, the goal of safe motherhood programs over the last decade and a half, has proved elusive. This may be due in part to the fact that safe motherhood programs often have been created on the basis of ideas that initially seemed good but had not been demonstrated to be effective. Two recent studies led by Council researchers have highlighted the need for identifying effective approaches before implementing them on a large scale.

\section{Self-reporting of symptoms}

Ninety-nine percent of maternal deaths occur in developing countries, where fewer than 50 percent of women give birth in health facilities. In these resource-poor settings, life-threatening obstetric conditions often go unidentified. Women do not know when they require special obstetric care, and in rural areas where health services are scarce, pregnancy complications are frequently not properly managed.

Attempts to use risk factors to predict which women are likely to experience serious complications have been unsuccesfful. Researchers had hoped that women's selfreports of symptoms could be used as a means to indicate life-threatening complications requiring referral and management.

In conjunction with the Kintampo Health Research Centre, Ghana, Council researchers conducted a retrospective study to determine whether it was possible to use women's selfreported obstetric symptoms to identify pregnancy complications. The investigators interviewed and assessed 340 consenting women who presented themselves to the Holy Family Hospital from the seventh month of pregnancy to 42 days postpartum.

Researchers used clinical examination and laboratory testing to determine women's health status. Self-reported symptoms were then compared with clinical findings of obstetric complications. Sixty-seven women (20 percent) experienced one or more complications. Complex al gorithms correctly identified the majority of complicated and uncomplicated pregnancies. These tools, however, missed 24 percent of cases requiring emergency obstetric care and incorrectly identified 25 percent of uncomplicated cases as requiring special obstetric management. Simple individual questions that could be used at the community level did not predict obstetric complications.

These findings are consistent with results from studies conducted in rural settings in other developing countries. Together, these studies show that the symptoms that best identified each obstetric condition varied across cultures. Therefore, algorithms to identify which women require referral would need to be developed and tested individually for each location. Given current knowledge and diagnostics, health programs are unlikely to develop succesful systems to identify and refer women for obstetric management in areas with limited health care services.

\section{Causes of maternal death}

In developing countries where medical services are scarce, many women deliver at home. In general, understanding of the medical and social causes of maternal death is incomplete because it is based on reports, called "verbal autopsies," of relatives and neighbors who have no medical training. In Mexico, the Council conducted a large "verbal autopsy" study to identify the causes of maternal death and disease. Data pertaining to 145 maternal deaths that occurred in 1995 in the states of Guerrero, Querétaro, and San Luis Potosí were reanalyzed.

Using the same data, but comparing different systems of classification, the researchers' calculations showed large variations in the attributed causes of women's deaths. The analyses, for example, demonstrated that postpartum hemorrhage might play a role in anywhere between 14 percent and 52 percent of maternal deaths.

In addition to demonstrating the inherent limitations of the verbal autopsy methodology, the study also reconfirmed that mortality among poor women with little access to medical care is substantially higher than that among wealthier women who have better access to institutional delivery and postpartum care.

"This study suggests that al though we know, in principle, the major medical causes of maternal death, we do not know the relative contribution of these various causes," says Population Council program associate Nancy L. Sloan, lead author of the article. However, she contends, program managers may not al ways need this knowl edge to save women's lives. Over half of the 145 maternal deaths were associated with more than one complication. But preventing or managing any one of these conditions- postpartum hemorrhage, for example- could potentially save lives by reducing the gravity of the other obstetric conditions women experience.

"While we must continue our efforts to ensure adequate emergency obstetric care for all," says Beverly Winikoff, director of the Council's reproductive health program, "there may be ways to prevent life threatening obstetric conditions that could feasibly and significantly reduce deaths." Population Council researchers are currently conducting a study of a strategy for reducing the incidence and severity of postpartum hemorrhage among women having home births in rural areas.

\footnotetext{
SOURCES

Sloan, Nancy L., Esi Amoaful, Paul Arthur, Beverly Winikoff, and Sam Adjei. 2001 "Validity of women's self-reported obstetric complications in rural Ghana", J oumal of Health, Population and Nutrition 19(2): 45-51

Sloan, Nancy L., A. Langer, B. Hernandez, M. Romero, and B. Winikoff. 2001 "The etiology of matemal mortality in developing countries: What do verbal autopsies tell us?" Bulletin of the World Health Organization 79(9): 805-810.
}

OUTSIDE FUNDING

Canadian International Development Agency, UNICEF, and The World Bank 


\section{Motivations for and Barriers to Study Participation}

\begin{abstract}
What factors motivate people to partici pate in clinical trials? While participants may potentially reap benefits, the products being tested are, by definition, unproven. To gain insight into this question - particularly in reference to trials of microbicides- Population Council researchers, with colleagues at the Thailand Ministry of Public Health- U.S. Centers for Disease Control and Prevention Collaboration, recently assessed the interests and concerns of

in the interviews. Before being interviewed, the women attended a brief informational session on microbicides and the requirements of a hypothetical clinical trial.

Eleven of the survey questions tested comprehension of information presented on microbicides and clinical trials. Eighty-two percent of the women answered eight or more of these questions correctly, while only 10 percent answered five or more questions incorrectly.
\end{abstract} women in Chiang Rai, Thailand regarding participation in microbicide clinical trials. Findings from this and similar research may prove valuable for sel ecting trial sites, estimating enrollment rates, and tailoring trials to best meet women's needs.

Microbicides are products, such as gels, creams, or other formulations, designed to prevent sexually transmitted infections, including HIV, when applied vaginally or rectally before intercourse. While no microbicides are currently approved, a number of them - including one developed by the Council, known as Carraguard $^{\prime \prime}$ - are being tested.

\section{Representative population}

Many effectiveness trials of candidate microbicides have been conducted among sex workers. This practice, however, is not ideal. "Sex workers may have mucosal irritation from frequent intercourse," says Population Council researcher Charlotte Ellertson, "which might negate ben efits of an otherwise effective microbicide." Many researchers would prefer to test microbicides among women who are more representative of the general population.

Investigators chose to study women in Chiang Rai, the northernmost province of Thailand, because the region has a high rate of HIV infection. They used a structured questionnaire to interview 370 women recruited from an antenatal and a family planning clinic. The survey questions were developed on the basis of findings from a series of focus group discussions and in-depth interviews of women and men in the province; only women participated

\section{"Doing something good}

for women's health"

was the most impor-

tant motivation in

deciding to join a trial.

After the short informational session, women were able to understand the most important concepts about microbicides and participation in clinical trials.

\section{Motivations and barriers}

The researchers asked the participants to rank each of 13 motivations for trial participation as "most important," "very important," "some what important," or "not at all important." Eighty-two percent said that "getting tested for HIV during trial participation" was very important, whereas only 34 percent thought that getting reimbursed for travel costs was very important. Nearly half the women, however, thought this factor was somewhat important. When asked which motivation was the single most important in deciding to join a trial, "doing something good for women's health" was most often ( 35 percent) cited.

The researchers al so asked participants to rank each of 19 barriers to trial participation as "most important," "a major problem," "a small problem," or "not a problem." Forty-six percent of participants said that the fear that using a microbicide might cause their husband to feel protected and thus to have more sexual partners was a major problem. Forty-two percent of women thought that "deciding to participate in the trial without your husband's consent" was a major problem. More than 60 percent of women, however, stated that the need for regular follow-up was not a problem, and 67 percent said that fear of receiving HIV results was not a problem. When asked to name the single most important barrier to trial participation, women most often ( 27 percent) cited the fact that longterm side effects of a microbicide are not known.

Most women (two-thirds) said they thought they would be willing to participate in a trial, but wanted to consider the matter further. Roughly 6 percent asserted they were definitely willing to participate in a trial, and less than 3 percent said they were not at all willing to participate.

Noting that a similar study conducted in Bangkok regarding vaccine trials found a much higher proportion of people ( 51 percent) definitely willing to participate in trials, Council researcher Kelly Blanchard stated that "some uncertainty about trial participation may come from a lack of familiarity with microbicides as a concept. Information for potential trial participants and good counseling might mean more women would be willing to participate." Given that the two factors most frequently cited as a major problem involve women's husbands, the researchers concluded that outreach and education for men about microbicides would also be useful.

\section{SOURCE}

Tharawan, Kanokwan, Chomnad Manopaiboon, Charlotte Ellertson, Khanchit Limpakarnjanarat, Supapom Chaikummao, Peter H. Kilmarx, Kelly Blanchard, Christiana Coggins, Timothy D. Mastro, and Christopher Elias. 2001 “'Women's willingness to participate in microbicide trials in northern Thailand," J ournal of Acquired Immune Deficiency Syndromes 28(2): 180-186. 


\section{Center for Biomedical Research}

BERNARD, D.J ., S.C. Chapman, and T.K. Woodruff. "M echanisms of inhibin signal transduction," Recent Progress in Hormone Research 56: 417-450.

BernaRd, D.J . and T.K. Woodruff. "Genetic approaches to the study of pituitary follicle-stimulating hormone regulation," in M.M. Matzuk, C.W. Brown, and T.R. Kumar (eds.), Transgenics in Endocrinology. Totowa, NJ : Humana Press, pp. 297-317.

- - - . "Inhibin binding protein in rats: Alternative transcripts and regulation in the pituitary across the estrous cycle," Molecular Endocrinology 15(4): 654-667.

Brandell, R.A. and P.N. SCHLEGEL. "M ale infertility," in R.M. Weiss, N.J .R. George, and P.H. O'Reilly (eds.), Comprehensive Urology. London: M osby, pp. 583-596.

Chan, P.T.K., G.D. Palermo, L.L. Veeck, Z.R.

Rosenwaks, and P.N. SCHLEGEL. "Testicular sperm extraction combined with intracytoplasmic sperm injection in the treatment of men with persistent azoospermia postchemotherapy," Cancer 92(6): 1632-1637.

Frank, I. and M. Pope. "Consequences of dendritic cell (DC)-immunodeficiency virus interactions: Chemically inactivated virus as a model for studying antigen presentation and virus transmission by primate DCs," Immunobiology 204: 622-628.

Kamp, C., K. Huellen, S. Fernandes, M. Sousa, P.N . SCHLEGEL, A. M IELNIK, S. Kleiman, H. Yavetz, W. Krause, W. Küpker, R. J ohannisson, W. Schulze, W. Weidner, A. Barros, and P.H. Vogt. "High deletion frequency of the complete AZFa sequence in men with Sertoli-cellonly syndrome," Molecular Human Reproduction 7(10): 987-994.

Kum AR, S., M. Angervo, M .K. BAGCH, and I.C. BaGCHI. "Isolation of steroid-regulated genes from the uterus by mRNA differential display," in B.A. Lieberman (ed.), Steroid Receptor M ethods, Protocols and Assays. Totowa, NJ : Humana Press, pp. 105-117.

KumAR, S., Q. Li, A. Dua, Y.-K. Ying, M.K. BAGCHI, and I.C. BAGCHI. "M essenger ribonucleic acid encoding interferon-inducible guanylate binding protein 1 is induced in human endometrium within the putative window of implantation," J ournal of Clinical Endocrinology and Metabolism 86(6): 2420-2427.

Li, P.S., M. Goldstein, and P.N. SChlegel. "Surgical sperm retrieval: Which method to use?" National J ournal of Andrology 7: 71-78.

Li, Q., M. Zhang, S. Kum AR, L.-J . Zhu, D. Chen, M.K. BAGCHI, and I.C. BAGCHI. "Identification and implantation stage-specific expression of an interferon- $\alpha$-regulated gene in human and rat endometrium,"

Endocrinology 142(6): 2390-2400.

Ohebshalom, M.M, J .A. Tash, D. Coll, L.-M. Su, and P.N. SCHLEGEL. "M assive hematuria due to right renal artery mycotic pseudoaneurysm in a patient with subacute bacterial endocarditis," Urology 58(4): 607.

Page, K.C., C.M. SotTAS, and M.P. HARDY. "Prenatal exposure to dexamethasone alters Leydig cell steroidogenic capacity in immature and adult rats," J ournal of Andrology 22(6): 973-980.

Pavlovich, C.P., P. King, M. GoldSTEIN, and P.N SCHLEGEL. "Evidence of a treatable endocrinopathy in infertile men," J ournal of Urology 165(3): 837-841.
SCHLEGEL, P.N. "Inguinal hernia after radical retropubic prostatectomy for prostate cancer: Study of incidence and risk factors in comparison to no operation and lymphadenectomy," editorial comment, J ournal of Urology 166(3): 967

- - - . "Sperm retrieval techniques," in J .M. Healy (ed.), Advances in Fertility and Sterility. London: Parthenon Publishing, pp. 371-382.

- - - . "W hat's new in urology?" J ournal of the American College of Surgeons 193(2): 179-201. SCHLEgel, P.N., S.K. Girardi, and E.D. Vaughan. "Cancer of the prostate," in K.I. Blandy, J.M. Daly, and C.P. Karakousis (eds.), Surgical Oncology: Principles and Practice. New York: M cGraw-Hill, pp. 813-838.

Schlegel, P.N., P. Kuzma, J . Frick, A. Farkas, A. Gomahr, I. SPITZ, B. Chertin, D. M ack, A. J ungwirth, P. King, H. NASH, C.W. Bardin, and A. M oo-Young. "Effective longterm androgen suppression in men with prostate cancer using a hydrogel implant with the GnRH agonist histrelin," Urology 58(4): 578-582.

Tash, J.A. and P.N. Schlegel. "Histologic effects of testicular sperm extraction on the testicle in men with nonobstructive azoospermia," Urology 57(2): 334-337. Travis, A.J ., T. M erdiushev, L.A. Vargas, B.H. J ones, M .A. Purdon, R.W. Nipper, J . Galatioto, S.B. M oss, G.R. HUnNICUTT, and G.S. Kopf. "Expression and localization of Caveolin-1, and the presence of membrane rafts, in mouse and guinea pig spermatozoa," Developmental Biology 240(2): 599-610.

Zini, A., M .K. O'B ryan, and P.N. SCHLEgel. "Nitric oxide synthase activity in human seminal plasma," Urology 58(1): $85-89$.

\section{International Programs Division}

Auvert, B., R. Ballard, C. Campbell, M. Carael, M. Carton, G. Fehler, E. Gouws, C. M acPhail, D. Taljaard, J ohannes van Dam, and B. Williams. "HIV infection among youth in a South African mining town is associated with herpes simplex virus-2 seropositivity and sexual behaviour," AIDS 15(7): 885-898.

Bhatti, L.I. and FARIYAL FIKREE. "Health-seeking behavior of Karachi women with reproductive tract infections," Social Science and Medicine 54(1): 105- 117.

Bhurt, A.W., Fariyal FiKree, A.M . Bhurt, N.M . Bozdar, N. Bhurt, A. Bhurt, and R. B hurt. "Utero-vaginal prolapse in a rural community of Sindh, Pakistan," J ournal of the College of Physicians and Surgeons Pakistan 11(1): 42-46.

Brady, M artha, Batya Elul, Shelley Clark, S. Vishwanath, and S. Rabindranathan. From Patna to Paris: Providing Safe and Humane Abortion. Quality/Calidad/Qualité no. 11. New York: Population Council.

Coetzee, N., Kelly B lanchard, Charlotte Ellertson, A.A. Hoosen, and Barbara Friedland. "Acceptability and feasibility of M icralax applicators and of methyl cellulose gel placebo for large-scale clinical trials of vaginal microbicides," AIDS 15(14): 1837-1842.

Costello, M arilou, M arlina Lacuesta, Saum ya RamaRao, and Anrudh J ain. "A client-centered approach to family planning: The Davao Project," Studies in Family Planning 32(4): 302-314.

Costello Daly, Celine, Vaishal Sharma M ahendra, and Pankaja Bhattarai. "Human rights and trafficking: Supporting women in Nepal," Global AIDSLink 69: 4.
Coyaji, Kurus, Batya Elul, Usha Krishna, Suhas Otiv, Shubha Ambardekar, Arti Bopardikar, Veena Raote, Charlotte Ellertson, and BeVerly W inikoff. "M ifepristone abortion outside the urban research hospital setting in India," Lancet 357(9250): 120-122. Ellertson, Charlotte, S. Ambardekar, A. Hedley, K. Coyaji, J . Trussell, and Kelly B LanChard. "Emergency contraception: Randomized comparison of advance provision and information only," Obstetrics and Gynecology 98: 570-575.

Ellertson, Charlotte and Sandra Waldman. "The mifepristone-misoprostol regimen for early medical abortion," Current Women's Health Reports 1(3): 184-190.

Erulkar, Annabel. See Mensch, Clark, Lloyd, and Erulkar (Policy Research Division).

Guilherme Penteado, Luis, Francisco Cabral, M argarita Díaz, J Uan Díaz, Laura Ghiron, and Ruth Simmons. "Organizing a public-sector vasectomy program in Brazil," Studies in Family Planning 32(4): 315-328. Hakim, Abdul and Peter C. M Iller. "Family planning in Pakistan: A turning point," in Zeba Ayesha Sathar and $J$ ames F. Phillips (eds.), Fertility Transition in South Asia. New York: Oxford University Press, pp. 135- 157. Hawkes, Sarah. "Human immunodeficiency virus and hepatitis in Bangladesh: Widespread or targeted prevention strategies?" International J ournal of Epidemiology 30(4): 885-886.

Huntington, Dale. "Abortion in Egypt: Official constraints and popular practices," in Carla M akhlouf Obermeyer (ed.), Cultural Perspectives on Reproductive Health. New York: Oxford University Press, pp. 175-192.

J AIN, ANRUDH. "Family planning programs: Quality of care," in Neil J . Smelser and Paul B. Baltes (eds.), International Encyclopedia of the Social and Behavioral Sciences, vol. 8. London: Elsevier Science, pp. 5340-5343.

- - - . "Population policy implications of the 1994 International Conference on Population and Development (ICPD)," in Zeba Ayesha Sathar and $\mathrm{J}$ ames F. Phillips (eds.), Fertility Transition in South Asia. New York: Oxford University Press, pp. 386-400. J ejeebhoy, Shireen J and Zeba A. Sathar. "Women's autonomy in India and Pakistan: The influence of religion and region," Population and Development Review 27(4): 687-712.

Kazi, Shahnaz and Zeba A. Sathar. "The relative roles of gender and development in explaining fertility in rural Punjab," in Zeba Ayesha Sathar and J ames F. Phillips (eds.), Fertility Transition in South Asia. New York: Oxford University Press, pp. 242-262.

Khan, M.E., Nayan Kumar, Bella C. Patel, Shalini Sikri, and Priya George. "Infertility: Its causes and consequences in Indian scenario," in C.P. Puri and P.F.A. Van Look (eds.), Sexual and Reproductive Health: Recent Advances, Future Directions, vol. II. New Delhi, India: New Age International, pp. 309-326. Khan, M.E., Bella C. Patel, and J ohn W. Townsend. Strengthening Social Science Research on Women's Health: Lessons Learned from a Capacity Building Programme. New Delhi, India: Population Council. M AITRA, KuHu. "Priority actions for safe motherhood: What are the challenges?" Health for the Millions 27(3): 7-8.

Publications are by Population Council staff members and consultants. Year of publication is 2001 unless otherwise noted. Names in caps are staff members in the division. Interdivisional publications appear as full reference in first author's division and cross-reference in coauthor's division. 
M AITRA, KUHU, J oseph Degraft-J ohnson, Kaushalendra K. Singh, and Amy 0 . Tsui. "Prevalence of self-reported symptoms of reproductive tract infections among recently pregnant women in Uttar Pradesh, India," J ournal of Biosocial Science 33(4): 585-601.

Mane, Purnima. "Behavior change in the lives of women: Lessons learned in the context of HIV/AIDS," in Fabrizio Butera and Gabriel M ugny (eds.), Social Influence in Social Reality. Toronto: Hogrefe \& Huber. M ane, Purnim A and Peter Aggleton. "Gender and HIV/AIDS: What do men have to do with it?" Current Sociology 49(6): 23-37.

M ayaud, P., D.K. Gill, H.A. Weiss, E. Uledi, L. Kopwe, J. Todd, G. ka-Gina, Heiner GrosskurTh, R.J . Hayes, D.C. M abey, and C.J . Lacey. "The interrelation of HIV, cervical human papillomavirus, and neoplasia among antenatal clinic attenders in Tanzania," Sexually Transmitted Infections 77(4): 248-254

NaYyar, ANJ ALI. "Increasing access to emergency contraception in India," Health and Population: Perspectives and Issues 23(3): 123-133.

NGom, Pierre, Fred N. Binka, J ames F. Phillips, B rian Pence, and Bruce Macleod. "Demographic surveillance and health equity in sub-Saharan Africa," Health Policy and Planning 16(4): 337-344.

Pachauri, SaroJ . "Foreword," in N.P. Das, M.M. Gandotra, Divya Pandey, and Urvi Shah (eds.), Status of Women and Reproductive Behaviour Among Urban Indian Women: Understanding the Linkages. New Delhi, India: Hindustan Publishing Corporation.

- - - . "Foreword," in M .E. Khan, Bella C. Patel, and J OHN W. TOWNSEND, Strengthening Social Science Research on Women's Health: Lessons Learned from a Capacity Building Programme. New Delhi, India: Population Council, p. v.

- - - . "Translating the ICPD agenda in India," in C.P. Puri and P.F.A. Van Look (eds.), Sexual and Reproductive Health: Recent Advances, Future Directions, vol. I. New Delhi, India: New Age International, pp. 123-156.

Ryan, E.T., E.A. B ridges, T.I. Crean, K. Gausia, J.D. Hamadani, A. Aziz, Sarah Hawkes, M. Begum, J. Bogaerts, S.M . Faruque, M .A. Salam, G.J . Fuchs, and S.B. Calderwood. "Local production of anti-vibrio cholerae mucosal antibody in reproductive tract tissues after cholera," J ournal of Infectious Diseases 184(5): 643-647. Saleem, S. and Fariyal FikreE. "Induced abortions in low socio-economic settlements of Karachi, Pakistan: Rates and women's perspectives," J ournal of the Pakistan Medical Association 51(8): 275-279.

Sathar, Zeba A. and J ames F. Phillips. "Introduction," in Zeba Ayesha Sathar and J ames F. Phillips (eds.), Fertility Transition in South Asia. New York: Oxford University Press, pp. 1-20.

Sathar, Zeba Ayesha and J ames F. Phillips. (eds.). Fertility Transition in South Asia. New York: Oxford University Press.

Sloan, Nancy L., BeVerly W Inikoff, and Fariyal F. Fikree. "Commentary: An ecologic analysis of maternal mortality ratios," Studies in Family Planning 32(4): 352- 355.

Tharawan, K., C. M anopaiboon, Charlotte Ellertson, K. Limpakarnjanarat, S. Chaikummao, P.H. Kilmarx, KeLLY BLANCHARD, C. Coggins, T.D. M astro, and Christopher Elias. "Women's willingness to participate in microbicide trials in northern Thailand," J ournal of Acquired Immune Deficiency Syndromes 28(2): 180- 186.

Verma, Ravi K., GuRum URTHy Rangaiyan, Rajender Singh, Sumitra Sharma, and Pertti J . Pelto. "A study of male sexual health problems in a M umbai slum population," Culture, Health \& Sexuality 3(3): 339-352. Weiss, H.A. and Sarah Haw KES. "An overview of the global epidemiology of HIV/AIDS," Leprosy Review 72(1): 92-98.

\section{Reports}

Bao, Vu N goc, Philip Guest, J ulie Pulerwitz, Le Thuy Lan THAO, and Duong Xuan Dinh. "M otivating companies to participate in workplace HIV/AIDS programs: Construction companies in Ho Chi M inh City, Vietnam." Hanoi, Vietnam: Population Council. BaO, Vu NGoc, and Pham Tung Lam. "The soccer and HIV/AIDS prevention education program for disadvantaged youth in Hanoi." Hanoi, Vietnam: Population Council.

Chege, J Ane, IAn Askew, and J ennifer Liku. "An assessment of the alternative rites approach for encouraging abandonment of female genital mutilation in Kenya," Frontiers report. Nairobi, Kenya: Population Council.

Costello Daly, Celine, Vaishali Sharma Mahendra, Pankaja Bhattarai, Nick Langton, J yoti Sanghera, Catrin Evans, Ratna Kapur, Dilli Ram Dahal, and Siobhan Crowley. "Trafficking and human rights in Nepal: Community perceptions, policy and program responses," research summary. New Delhi, India: Population Council.

Diop, Nafissatou et al. "Etude exploratoire du vécu des adolescentes mariées et de leurs besoins en opportunités économiques et en santé de la reproduction à Louga et Saint-Louis" [Exploratory study of married adolescent life experiences, their need for economic opportunities, and reproductive health needs in Louga and Saint-Louis]. Dakar, Senegal: Population Council.

Diop, Nafissatou et al. "Etude pour l'amélioration de la santé de la reproduction des adolescents à Louga et Saint-Louis: Enquête de base" [Improving adolescent reproductive health in Louga and Saint-Louis: Baseline study]. Dakar, Senegal: Population Council. Diop, Nafissatou et al. "Evaluation d'un programme d'éducation à base communautaire pour améliorer la santé de la reproduction des femmes et lutter contre l'excision à Kolda: Enquête de base" [Assessment of a community-based educational program to improve women's reproductive health and reduce female genital cutting in Kolda: Baseline study]. Dakar, Senegal: Population Council, GTZ, and Tostan.

Diop, Nafissatou et al. "Tester un programme d'éducation à base communautaire pour améliorer la santé de la reproduction des femmes et lutter contre l'excision au Bazéga au Burkina Faso: Enquête de base" [Pilot-testing a community-based educational program to improve women's reproductive health and reduce female genital cutting in Bazega, Burkina Faso: Baseline study]. Ouagadougou, Burkina Faso: Population Council, GTZ, and M wangaza.

ERULKar, Annabel S., Mags Beksinska, and Queen Cebekhulu. "An assessment of youth centres in South Africa," Frontiers final report. Nairobi, Kenya: Population Council.

Evans, Catrin, Pankaja Bhattarai, Celine Costello Daly, Vaishal Sharma Mahendra, and Nick Langton. "A comparative analysis of anti-trafficking intervention approaches in Nepal." New Delhi, India: Population Council.

"Facts about adolescents from the Demographic and Health Survey: Statistical tables for program planning," a series of 46 country reports analyzing DHS data describing adolescents' lives. New York: Population Council.

Firmansyah, Wanda, Sahar Hegazl, Siti Rokhmawati Darwisyah, and Lila Amaliah. "Increasing coverage of reproductive health issues in the Indonesian print media." J akarta, Indonesia: Population Council. Hawkes, Sarah, J ohannes van Dam, Kevin O'Reilly, Bidia Deperthes, AnJ ALI NAYYAR, and Dinesh Agarwal. "Reproductive tract infections: A guide for programme managers." New Delhi, India: UNFPA and Population Council.
"HIV voluntary counselling and testing among youth Results from an exploratory study in Nairobi, Kenya, and Kampala and Masaka, Uganda," Horizons report with Kenya and Uganda project partners. Washington, DC: Population Council.

Lambert, H., S. B harat, G. Bhave, G. Davey-Smith, Heiner Grosskurth, S. J aswal, and S. Panda. "Situational analysis of sexual health in India (SASHI): Implementation package: NACO, DFID." New Delhi, India: Department for International Development.

Leonard, Ann, Purnima Mane, and Nami Rutenberg. "Evidence for the importance of community involvement: Implications for initiatives to prevent mother-tochild transmission of HIV," Community Involvement in Initiatives to Prevent M other-to-Child Transmission of HIV: A Collaborative Project. New York: Population Council, pp. 1-32.

M ahendra, Vaishali Sharma, Pankaja Bhattarai, Dilli Ram Dahal, Siobhan Crowley, Celine Costello Daly, and Nick Langton. "Community perceptions of trafficking and its determinants in Nepal." New Delhi, India: Population Council.

M Al, Le ThI PhuOng and Lucinda Willshire. "Tackling domestic violence in rural communities of Vietnam: Results from an initial survey." Hanoi, Vietnam: Population Council.

M iller, Suellen, Rasha Dabash, Elba M ercado, Ellin $\mathrm{K}_{\mathrm{AO}}$, and Pamela Putney. "Documento de antecedentes del estado de los servicios de salud reproductiva en la República Dominicana" [Background paper on the status of reproductive health services in the Dominican Republic].

NaYYAR, AnJ ALI. "M edia advocacy for emergency contraception," in Consortium on National Consensus on Emergency Contraception: Report and

Recommendations. New Delhi, India: M inistry of Health and Family Welfare, W HO, and Indian Council of Medical Research.

- - - . "Role of information technology in health and education sector: Hopes, challenges and attendant risks," in Role of Information Technology in Rural Social Sector: A Report. New Delhi, India: M inistry of Human Resource Development and Adhya.

Nhan, Vu Quy, Le Thi Phuong Mal, and Nguyen Thi Thom. "A baseline survey on public-sector reproductive health service in Nghe An province." Hanoi, Vietnam: Population Council.

$--\ldots$. "Situation analysis of public-sector reproductive health services in Quang Nam province." Hanoi, Vietnam: Population Council.

Piet-Pelon, Nancy J and Sharif M OHAm m Ad ISMAIL Hossain. "Success stories in Bangladesh and future directions for the country programme." Dhaka, Bangladesh: UNFPA and Population Council.

"Power in sexual relationships: An opening dialogue among reproductive health professionals." New York: Population Council.

Sanghera, J yoti, Ratna Kapur, Celine Costello Daly, Vaishali Sharma M ahendra, Pankaja Bhattarai, and Nick Langton. "Trafficking in Nepal: An assessment of laws and policies for the prevention and control of trafficking in Nepal." New Delhi, India: Population Council.

Sanogo, Diouratié, M backé Niang et al. "Comment promouvoir l'utilisation des résultats d'une analyse situationnelle à l'échelle nationale: Expérience du Sénégal" [How to promote the use of situation analysis results at the national level: The Senegalese experience], Frontiers report. Dakar, Senegal: Population Council. 
Stewart, Holley, Ann M cCauley, Sim on Baker, Martha Givaudan, Shegs I ames, Iwin Leenen, Susan Pick, Priscilla Reddy, Usasinee Rewthong, Patchara Rum AKom, and Dilys Walker. "Reducing HIV infection among youth: What can schools do? Key baseline findings from M exico, South Africa, and Thailand," Horizon program report. Washington, DC: Population Council.

TAPSOBA, PlaCide et al. "Collecte de l'information pour la prévention des IST et du VIH/SIDA chez les hommes ayant des relations sexuelles avec d'autres hommes à Dakar" [Collecting information for STI and HIV/AIDS prevention from men having sex with men in Dakar], Horizons report. Dakar, Senegal: Population Council, Programme National de Lutte contre le SIDA, and Institut des Sciences de l'Environnement.

TAPSOBA, PlaCIDE et al. "Sexualité cónjùgale et prévention des IST/VIH/SIDA chez les femmes enceintes: Implication du conjoint, contexte socioculturel et offre de services" [Sexuality among couples and STI/HIV/AIDS prevention among pregnant women: M en's involvement, social and cultural background, and services offered], Horizons report. Dakar, Senegal: Population Council and Programme National de Lutte contre le SIDA.

Varkey, Leila Caleb and Anj ana Das. "Getting husbands involved in maternity care: An urban Indian perspective," in Safe Motherhood at Home: Realities, Perspectives and Challenges. A Symposium Report. White Ribbon Alliance for Safe M otherhood.

Verma, Ravi K. and Gurumurthy Rangaiyan. "A study of male sexual health problems and treatment seeking behaviour in a M umbai slum population," M umbai, India: International Institute for Population Sciences. Warren, Charlotte, J ane Chege, lan Askew, Samson Radeny, and Michelle Folsom. "Improving the reproductive health of adolescents in Kenya," Frontiers report. Nairobi, Kenya: Population Council.

\section{Working Paper}

Hawkes, Sarah and K.G. Santhya. "Diverse realities: Understanding sexually transmitted infections and HIV in India," Regional Working Paper no. 15. New Delhi, India: Population Council.

\section{Newsletters and Updates}

Diop, Nafissatou et al. "Le point sur une expérience en cours: Etude sur l'amélioration de la santé de la reproduction des adolescents au Sénégal" [Status of an ongoing study: Improving adolescent reproductive health in Senegal]. Dakar, Senegal: Population Council and Service National de la Santé de la Reproduction.

Grupo de Trabajo sobre Derechos Sexuales y Reproductivos [Working group on sexual and reproductive rights]. "Desyres de la sexualidad" no. 1. M exico City: Population Council, Fundación M exicana para la Planeación Familiar, M EXFAM, Frente por el Fortalecimiento de la Cultura Laica, and the Interdisciplinary Program of Women Studies of El Colegio de México.

- - - . "Desyres de la sexualidad: Aborto: Afirmación privada, negación pública" [Abortion: Private affirmation, public rejection] no. 2. M exico City: Population Council, Fundación Mexicana para la Planeación Familiar, M EXFAM , Frente por el Fortalecimiento de la Cultura Laica, and the Interdisciplinary Program of Women Studies of El Colegio de México.

- - - . "Desyres de la sexualidad: La sexualidad: Entre mitos, placeres y esperanzas" [Sexuality: $M$ yths, pleasures, and expectations] no. 3. M exico City: Population Council, Fundación Mexicana para la Planeación Familiar, M EXFAM , Frente por el Fortalecimiento de la Cultura Laica, and the Interdisciplinary Program of Women Studies of El Colegio de M éxico.
- - - . "Desyres de la sexualidad: Derechos sexuales y reproductivos: Ser o no ser" [Sexual and reproductive rights: To be or not to be] no. 4. M exico City: Population Council, Fundación M exicana para la Planeación Familiar, M EXFAM , Frente por el Fortalecimiento de la Cultura Laica, and the Interdisciplinary Program of Women Studies of El Colegio de M éxico.

- _ - . "Desyres de la sexualidad: Nuevas tecnologías no anticonceptivas en salud sexual y reproductivo" [New contraceptive technologies in sexual and reproductive health] no. 5. M exico City: Population Council, Fundación M exicana para la Planeación Familiar, M EXFAM, Frente por el Fortalecimiento de la Cultura Laica, and the Interdisciplinary Program of Women Studies of El Colegio de M éxico.

"KARHP update" no. 1, project update of Frontiers Global Youth Agenda Project. Nairobi, Kenya: Population Council.

"Making pregnancy safer: Quarterly newsletter of the Safe M otherhood Project," 1(1). Nairobi, Kenya: Population Council.

Pamphlets

Diop, Nafissatou et al. "Savoir pour agir: Etude sur l'amélioration de la santé de la reproduction des adolescents au Sénégal" [Knowledge for action: Improving adolescent reproductive health in Senegal]. Dakar, Senegal: Population Council and Service National de la Santé de la Reproduction.

García, Sandra and D. Becker. "¿Qué piensan y opinan las y los mexicanos sobre el aborto? Resultados de una encuesta nacional de opinión pública" [W hat are the knowledge and opinions of M exican men and women regarding abortion? Findings from a national survey]. Population Council and Grupo IDM

Sanogo, Diouratié et al. "Approche d'offre SBC de SR à Kébémer: Un espoir annoncé pour les communautés rurales du Sénégal" [Strategy for reproductive health community-based services: Hope for rural communities in Senegal]. Dakar, Senegal: Population Council and Service National de la Santé de la Reproduction.

\section{Policy Research Division}

BongAaRTS, J OHN. "Dependency burdens in the developing world," in Nancy Birdsall, Allen C. Kelley, and Steven W. Sinding (eds.), Population Matters: Demographic Change, Economic Growth, and Poverty in the Developing World. New York: Oxford University Press, pp. 55-64.

- - - . "Fertility and reproductive preferences in post-transitional societies," in Rodolfo A. Bulatao and J OHN B. CASterline (eds.), Global Fertility Transition, supplement to Population and Development Review vol. 27. New York: Population Council, pp. 260-281.

- - - . "Household size and composition in the developing world in the 1990s," Population Studies 55 263-279.

BongaARTS, J ohn and Saj edA Amin. "Prospects for fertility decline and implications for population grow th in South Asia," in Zeba Ayesha Sathar and I AMES F. PHILlıs (eds.), Fertility Transition in South Asia. New York: Oxford University Press, pp. 401-422.

Bulatao, Rodolfo A. and J OHN B. CAsterLine (eds). Global Fertility Transition, supplement to Population and Development Review vol. 27. New York: Population Council.

CAsterline, J ohn B. "Diffusion processes and fertility transition: Introduction," in J OHN B. CAsterLINE (ed.), Diffusion Processes and Fertility Transition: Selected Perspectives. Washington, DC: National Academy Press, pp. 1-38.
- - - . "The pace of fertility transition: National patterns in the second half of the twentieth century," in Rodolfo A. Bulatao and J OHN B. CAsterLIne (eds.), Global Fertility Transition, supplement to Population and Development Review vol. 27. New York: Population Council, pp. 17-52.

- - - (ed.). Diffusion Processes and Fertility Transition: Selected Perspectives. Washington, DC: National Academy Press.

DAYTON, J ULIA and M ichael Merson. "The value of early detection of HIV in developing countries," International AIDS Society Newsletter 19(J uly): 8-10.

Frey, William H. and Zachary Zimmer. "Defining the city and levels of urbanization," in Ronan Paddison (ed.), Handbook of Urban Studies. Thousand Oaks, CA: Sage Publications, pp. 14-35.

M CN IColl, Geoffrey. "Fertility: Institutional and political approaches," in Neil J . Smelser and Paul B. Baltes (eds.), International Encyclopedia of the Social and Behavioral Sciences, vol. 8. London: Elsevier Science, pp. 5538-5543.

- - - . "Government and fertility in transitional and post-transitional societies," in Rodolfo A. Bulatao and J OHN B. CAsterline (eds.), Global Fertility Transition, supplement to Population and Development Review vol. 27. New York: Population Council, pp. 129-159. - - - . "IPAT (impact, population, affluence, and technology)," in Neil J . Smelser and Paul B. Baltes (eds.), International Encyclopedia of the Social and Behavioral Sciences, vol. 12. London: Elsevier Science, pp. 7903-7906.

- - - . Review of Richard Leete (ed.), Dynamics of Values in Fertility Change, in Population Studies 55(1): 97-99.

- - - . Review of Bjørn Lomborg, The Skeptical Environmentalist: M easuring the Real State of the World, in Population and Development Review 27(4): 801-804.

Mensch, Barbara S., Wesley H. Clark, Cynthia B. Lloyd, and Annabel S. Erulkar. "Premarital sex, schoolgirl pregnancy, and school quality in rural Kenya," Studies in Family Planning 32(4): 285-301.

Naved, Ruchira T., M argaret New by, and SAI EDA AM IN. "The effects of migration and work on marriage of female garment workers in Bangladesh," International J ournal of Population Geography 7(2): 91-104.

Pence, Brian. See Ngom, Binka, Phillips, Pence, and $M$ acleod (International Programs Division).

Phillips, J ames F. See Ngom, Binka, Phillips, Pence, and $M$ acleod (International Programs Division): Sathar and PHILLIPS (International Programs Division).

\section{Working Papers}

153 M ontgomery, M ark R., Gebre-Egziabher Kiros, Dominic Agyeman, J oHn B. CAsterline, Peter Aglobitse, and Paul C. Hewett. "Social netw orks and contraceptive dynamics in southern Ghana."

154 Hewett, Paul C. and M ark R. M ontgomery. "Poverty and public services in developing-country cities."

\section{Other Publications}

Demeny, Paul. "Intellectual origins of post-World War II population policies in South Asia," in Zeba Ayesha Sathar and J ames F. Phillips (eds.), Fertility Transition in South Asia. New York: Oxford University Press, pp. 331-346.

Population Briefs 7(4)

Population and Development Review 27(4)

Segal, Sheldon J . "Health effects of menstruation," in Proceedings of "Contraceptive Technology's Quest for Excellence," Contemporary Forums Conference. Studies in Family Planning 32(4) 


\section{Epidemiology}

continued from page 1

other STIs, especially ones that result in ulcerated lesions, may account for some increased transmission of HIV. In both cities, for example, the rate of infection with herpes simplex virus type 2 was roughly four times greater among young women than among young men. Even when no other STI was present, however, young women were still at higher risk for HIV infection. There is evidence of high rates of HIV positivity following only a few episodes of sexual intercourse, suggesting that young women have a high susceptibility to infection.

\section{Male circu mcision}

The exposure of mucosal surfaces to HIV-containing secretions may account for another discrepancy in HIV prevalence seen in sub-Saharan Africa. A growing body of research shows that uncircumcised men in sub-Saharan Africa are about twice as likely as circumcised men to be infected with HIV. The foreskin of the penis, which is removed during circumcision, is lined with a mucous membrane. The prevalence of male circumcision varies across the continent. In Yaoundé and Cotonou nearly all men studied were circumcised. In Kisumu, roughly 28 percent of men studied were circumcised and in Ndola the figure was only 9 percent.

The researchers found three HIV risk factors that were more prevalent in Kisumu and Ndola than in Cotonou and Yaoundé: being married or having been married (among women and men), lack of circumcision (among men), and increased infection with herpes simplex virus type 2 (among women). The HIV risk associated with marriage may reflect the exposure of men and women, through repeated sexual intercourse, to spouses infected with HIV.

The investigators found a strong protective effect of male circumcision in Kisumu. The prevalence of HIV, herpes simplex virus type 2, and syphilis was significantly lower in circumcised men there.

The researchers conclude that the evidence of circumcision's protective effect against $H I V$ is convincing and that the provision of safe male circumcision should be considered as part of the public health strategy to reduce the spread of HIV. "But more research is needed to determine acceptability, feasibility, and cost-effectiveness," assert the investigators. Moreover, interventions to introduce circumcision must be carefully evaluated as they proceed.

The Population Council's Horizons program recently developed a research agenda on male circumcision that should contribute to feasibility studies. USAID-funded Horizons research is conducted in collaboration with the International Center for Research on Women, the Program for Appropriate Technology in Health, the International HIV/AIDS Alliance, Tulane University, Family Health International, and Johns Hopkins University.

\section{Key implications}

In addition to highlighting the urgent need for more research and policy development regarding male circumcision, the study's findings suggest other key changes, say the researchers. "Infection with herpes simplex virus type 2 and $H I V$ are extremely prevalent in young women shortly after they begin sexual activity," says Chege. "Policymakers should strengthen community and school-based peer education for young women and men before they start sexual activity."

Additionally, "because HIV is likely to be transmitted between spouses, voluntary HIV counseling and testing among couples, particularly before marriage, should be encouraged," says Rutenberg. The researchers also called for community-based education to help people recognize the symptoms of herpes simplex virus type 2. During outbreaks, people infected with this virus can temporarily abstain from sex or use condoms in order to reduce transmission.

\section{SOURCES}

Auvert, B., A. Buvé, B. Ferry, M. Caraël, L. Morison, E. Lagarde et al. 2001 “Ecological and individual level analysis of risk factors for HIV infection in four urban populations in sub-Saharan Africa with different levels of HIV infection," AIDS 15(suppl 4): S15-S30.

Auvert, B., A. Buvé, E. Lagarde, M. Kahindo, J . Chege, N. Rutenberg et al. 2001 "Male circumcision and HIV infection in four cities in sub-Saharan Africa," AIDS 15(suppl 4): S31-S40.

Buvé, A., M. Caraël, R.J . Hayes, B. Auvert, B. Ferry, N.J . Robinson et al. 2001 "The multicentre study on factors determining the differential spread of HIV in

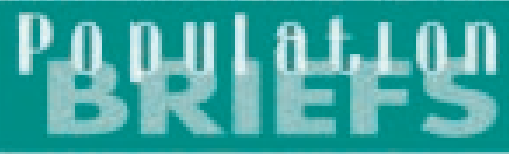

J uly 2002

Vol. 8, No. 1

Population Briefs is a research newsletter of the Population Council. The Council is an international,

nonprofit, nongovernmental organization that seeks to improve the well-being and reproductive health of current and future generations around the world and to help achieve a humane, equitable, and sustainable balance between people and resources. The Council conducts

biomedical, social science, and public health research and

helps build research capacities in developing countries.

Established in 1952, the Council is governed by an interna-

tional board of trustees. Its New York headquarters

supports a global netw ork of regional and country offices.

W riter/Editor

Gina Duclayan

Editorial Board

Anrudh J ain, Cynthia B. Lloyd,

Melissa May, Irving Sivin

Production M anager

Y. Christina Tse

Production Artist

Sura Rosenthal

Copyeditor

Robert Heidel

Editorial Assistant

J ared Stamm

Circulation

Debra Warn

Population Briefs is distributed without charge. Information in this newsletter may be reproduced without permission, provided it is distributed without charge and the source is acknowledged.

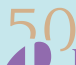

\section{Population Council}

One Dag Hammarskjold Plaza

New York, NY 10017

fax: (212) 755-6052

e-mail: pubinfo@popcouncil.org

http://ww w. popcouncil.org

To receive e-mail when a new issue of Population Briefs is posted to the Population Council Web site, register at our M edia Center: www.popcouncil.org/mediacenter/lists/default.html

Population Briefs is supported in part by the Turner Foundation. ISSN 1084-6786

(C) 2002 The Population Council, Inc.

Printed in the USA on recycled paper

four African cities: Summary and conclusions," AIDS 15(suppl 4): S127-S131

Glynn, J R., M. Caraël, B. Auvert, M. Kahindo, J . Chege et al. 2001 "Why do young women have a much higher prevalence of HIV than young men? A study in Kisumu, Kenya and Ndola, Zambia," AIDS 15(suppl 4): S51-S60.

van Dam, J ohannes and Marie-Christine Anastasi. 2000. "Male circumcision and HIV prevention: Directions for future research." Horizons project report. Washington, DC: Population Council. (http://www.popcouncil.org/horizons/reports/circumcision/default.html)

\section{OUTSIDE FUNDING}

Institute of Tropical Medicine, Antwerp and UNAIDS 